\title{
The Decalogue and Igbo Traditional Ethics: Essential Values for Community Building
}

\author{
Ikenna L. Umeanolue \& Emmanuel C. Anizoba \\ http://dx.doi./org/10.4314/ujah.v18i2.15
}

\section{Abstract}

The paper analyzes the Decalogue or Ten Commandments (Ex. 20:1-17) and Igbo traditional ethics as assets for community building. The giving of the Decalogue was an effort at building the Jewish community. Likewise Igbo traditional ethics provides moral values for Igbo community building. The Decalogue and Igbo traditional ethics have essential values for community building which include sense of the sacred, unity and fidelity. Both the Decalogue and Igbo traditional morality provide a sense of direction for the Jews and the Igbo respectively. They can be summarized as the love of God and the love of neighbour. When the Jewish people are compared with the Igbo people, one discovers that the Igbo have ground norms called omenala which stipulate moral codes guiding the lives of the people. Like the Jews, Igbo people have a sense of the covenant which they call igba-ndu and a sense of the sacred which they term nso-ala. With these the Igbo people build a sense of community. Thus the paper shows that the Ten Commandments and Igbo traditional ethics can be used as bases to tackle the challenges of Igbo community building. It is the conclusion of this paper that much community building can be achieved if the Igbo, who are predominantly Christians, can internalize the provisions and values of the Decalogue and Igbo traditional ethics. 


\section{Introduction}

The world is made up of ethnic nationalities. These ethnic nationalities have their lands and languages beautifying earth's landscape. Thus one hears of Igboland, Hausaland, Yorubaland, Jewishland and so forth. These lands as habitats enable each ethnic group to develop a culture that reveals their intelligent interaction with the environment. The cultures embody their perception with other people. By these cultures, a community sees and is seen. In these interactions, a community displays its unique qualities, differences and similarities with others. For instance the Jewish people who see themselves as the chosen people identify themselves with God, the covenant, and the Decalogue (or Ten Commandments) as contained in their Scripture, the Torah. For many centuries, the Ten Commandments provide for Jewish people a sense of direction. Jesus Christ made reference to the commandments and summarized it as love of God and love of neighbour. These were efforts at building up the Jewish community.

When the Jews are compared with the Igbo people, one discovers that Igbo people have ground norms called omenala which stipulate moral codes guiding the lives of the people. Like the Jews, Igbo people have a sense of the covenant which they call $i g b a-n d u$ and a sense of the sacred with they termed nso-ala. With these Igbo people develop a sense of community. According to Nzomiwu, (1999), an action which fits into the pattern outlined by tradition is regarded as straight and therefore just. A man who fulfils injunctions of omenala, which contains the duties of a citizen in both vertical and horizontal directions, is regarded as just man. Traditions are usually the experience life enhancing forces of 
a habitat that people come to cherish as custom which gradually become sacred to them. Rituals are developed to put them alive.

Ethnic nationalities are not island; they interact with each other and in this way enrich and enlarge themselves as Madu (2014) observes, "Cultures must necessarily interact, and in each case there must be elements of diffusion, assimilation and rejection on both sides. After all no culture can sufficiently satisfy the needs of its owners, and this explains the principle of cultural interactions. Cultures therefore necessarily accept other cultures that are relevant to them as well reject those which may run counter to their cherished ideals, values and practice (p. ix). Thus community building can be a mutual experience in accepting and rejecting cultural practices. This study seeks to understand the essential values of the Decalogue and Igbo traditional ethics for effective community building.

\section{Analysis of the Decalogue}

According to Kizhakkeyil (2009), "The set of laws in Ex 20:1-17 are called the Ten Commandments on the basis of Ex 34:28; 25:16; Deut $4: 13 ; 10: 4$ where they are explicitly named 'Ten Commandments"' (p. 266). The Decalogue is also found in Deut. 5:6-21 with slight changes. This study uses the text of The Decalogue (or Ten Commandments) as contained in Revised Standard Version. Thus:

${ }^{1}$ And God spoke all these words, saying, ${ }^{2}$ "I am the Lord your God, who brought you out of the land of Egypt, out of the house of bondage. ${ }^{3}$ You shall have no other gods before me. ${ }^{4}$ You shall not make for yourself a graven image, or any likeness of anything that is in heaven above, 
or that is in the earth beneath, or that is in the water under the earth; ${ }^{5}$ you shall not bow down to them or serve them; for I the Lord your God am a jealous God, visiting the iniquity of the fathers upon the children to the third and the fourth generation of those who hate me, ${ }^{6}$ but showing steadfast love to thousands of those who love me and keep my commandments. ${ }^{7}$ You shall not take the name of the Lord your God in vain; for the Lord will not hold him guiltless who takes his name in vain. ${ }^{8}$ Remember the Sabbath day, to keep it holy. ${ }^{9}$ Six days you shall labor, and do all your work; ${ }^{10}$ but the seventh day is a Sabbath to the Lord your God; in it you shall not do any work, you, or your son, or your daughter, your manservant, or your maidservant, or your cattle, or the sojourner who is within your gates; ${ }^{11}$ for in six days the Lord made heaven and earth, the sea, and all that is in them, and rested the seventh day; therefore the Lord blessed the Sabbath day and hallowed it. ${ }^{12}$ Honor your father and your mother, that your days may be long in the land which the Lord your God gives you. ${ }^{13}$ You shall not kill. ${ }^{14}$ You shall not commit adultery. ${ }^{15}$ You shall not steal. ${ }^{16}$ You shall not bear false witness against your neighbor. ${ }^{17}$ You shall not covet your neighbor's house; you shall not covet your neighbor's wife, or his manservant, or his maidservant, or his ox, or his ass, or anything that is your neighbor's." (Ex. 20:1-17).

The first commandment (v. 3) does not deny the existence of other gods, but declares that for Israel there is only one, that is Yahweh (cf. Deut. 5:7, 6:4; II Kings 17:35; Jer. 25:6). Yahweh is to be the only God Israel recognizes and worships. The theoretical question about the existence of other gods is not raised. 
The second commandment (vv. 4-6) prohibits the making of images, evidently as objects of reverence or worship, for Yahweh is a jealous God and will have no rival in the affections of his people (cf. Ex. 34:12-17; Lev. 26:1; Deut. 4:15-24). It is not easy for us to recognize the truth which lies in the words, "visiting the iniquity of the fathers upon the children' but the actual facts of the human life, consonant with the laws of nature, show that children do suffer for the sins of their parents. And these laws of nature are the laws of God. The complementary truth of individual responsibility is presented in Jer. 31:29, 30 and Ezek. 18.

The third commandment (v. 7) does not forbid the taking of an oath, but false swearing, and the light, irreverent, or insincere use of the name of God. Ordinary profane language is forbidden, even that which veils the name of God under apparently meaningless imitations of it (Lev. 19:12; Mt. 5:33-37). Clifford (2000) comments that the prohibition seems to be against the false use of an oath in legal proceedings rather than a general lack of reverence for the name.

The fourth commandment (vv. 8-11) enjoins the observance of the Sabbath as a holy day and a day of rest. The word Sabbath is taken directly from the Hebrew and means 'rest' or 'ceasing from labour'. There is a reference in v. 11 to the story of creation (Gen. $1: 1-23)$ where the work of God is presented, under the figure of the days of the week, as proceeding by orderly stages to completion and rest. The reason for the observance of the Sabbath in the parallel passage in Deut. 5:12-15, is simply that working people may rest (cf. 31:12-17; Lev. 19:30; Isa. 58:13, 14; Jer. 17:19-27). 
The fifth commandment (v. 12) stands as the point of transition from social to civil law. The honoring of parents is a form of piety, though not a cultic observance. In Deut. 5:16 prosperity is added to the promise of length of days in the land offered here. This commandment most especially refers to the treatment of helpless aged dependents. It is called by Paul "the first commandment with promise" (Eph. 6:2-3). The sixth commandment (v. 13) is concerned with the protection of human life within the community of Israel, against destruction by fellow Israelites. The verb is not limited to murder in the criminal sense and may be used of unpremeditated killing (Deut. 4:42). It forbids all kinds of killing not explicitly authorized. This means that in Israelite society it did not forbid the slaying of animals or the killing of enemies in war (Park, 1952).

The seventh commandment (v. 14) treats the family as a social unit. Its real concern is the sacredness of marriage; only by implication does it relate to the whole range of sexual morals. The verb on which the prohibition rests is used exclusively in the Old Testament of material infidelity or adultery, not fornication.

The eighth commandment (v. 15) is concerned with the sacredness of property. It is the basic commandment on which the idea of property rests. It is the protection which the diligent and prudent have against the idle and careless. The underlying conviction is, "I have toiled to collect these possessions, and you who have been idle must not rob me of the fruits of my industry". The ninth commandment (v. 16) sets forth the principle of the sacredness of the judicial system. The verb in the prohibition means to answer', i.e., at court, whether as plaintiff, defendant, or witness, a man must speak the truth in a charge involving his neighbour. The more 
general notions of talebearing and character assassination are perhaps not ruled out, but the central concern is the integrity of the judicial system. The tenth commandment (v. 17) forbids both the entertainment of covetous desire and the acts of cheating, violence, and oppression which spring from it (cf. Mic. 2:1-2). The story of Ahab's covetous desire for the vineyard of Naboth and the crime to which it led furnishes an example (I Kings 21:1-16).

The Decalogue (or Ten Commandments) has been regarded as the gift of God, through Moses, to the Israelite people (McLaughlin, 1929). The revelation of the Ten Commandments was a special moment. God had identified with the people of Israel for a long time. By the time the Decalogue was revealed, the people of Israel have experienced God as a friend, father and liberator. God was not for them an abstract being. This tenderness is revealed in the prayer an Israelite says on bringing the first fruits of the soil to God: A wandering Aramean was my ancestor; he went down into Egypt and lived there as an alien, few in number, and there he became a great nation, mighty and populous. When the Egyptians treated us harshly and afflicted us, by imposing hard labour on us, we cried to the Lord, the God of our ancestors; the Lord heard our voice and saw our affliction, our toil, and our oppression. The Lord brought us out of Egypt with a mighty hand and an outstretched arm, with a terrifying display of power, and with signs and wonders; and he brought us into this place and gave us this land, a land flowing with milk and honey (Deut. 26:5-9).

Commenting on this experience, Arazu (1994) says that "the Semite identified himself with his race. The history of his race was his personal history, and it was also sacred history. That is why he could recite that history as prayer" (p. 18). Arazu goes further to 
say that, "God's relation with Israel did not start with "thou shall not'. There was a long salvation history before law, and law came in as an essential part of the covenant that God made with Israel at the foot of Mount Sinai” (p. 21). The origin of the Decalogue dates back to that singular incident in Exodus 19:16-18 where a horde of Hebrew and other slaves who had escaped from bondage in Egypt trembled at the foot of smoking mountain and heard a voice in the midst of thunder and lightening. At that theophany the hordes that need not have been all the children of Jacob became his children through a covenant. Therefore, the Ten Commandments were part and parcel of the experience at Mount Sinai. They were items in the contract between God and the nation of Israel. They were the covenant code of conduct. The covenant determined what was good, and evil, virtue and vice.

\section{Basis of Igbo Traditional Ethics}

In Igbo traditional society religion is the basis of ethics and morality both through the sanctions imposed by custom and prohibitions. The world is believed to be created by Chineke (the God that creates) or Chukwu (Chi-Ukwu, the Great God). This Chineke is believed to be the author of heaven and earth who makes animal and plant life grow. He as the source of life and sustenance, which to an Igbo man is the chief good, becomes therefore the source of goodness and benevolence. He gives to each man at the time of his birth that man's particular portion of his divine essence known as Chi. Hence the Igbo name for the Supreme Being is Chi-Ukwu meaning the Great Chi in whom all human life and the sum total of individual Chi are gathered up. This Chi is like the personal spark of Chineke given to each person to guide him all his life. 
A religious concept that is very important in Igbo morality is Ala (The Earth Goddess). According to Ulogu (1985), "Ala is the most important divinity in Igbo social and moral life. She is the guardian of morality, the source of fruitfulness in women, vegetation and agricultural products. She ensures health and well being to the community by preventing the incidence of plague, famine, droughts, and barrenness among women" (p. 25). Because the dead ancestors are buried in the earth, the earth goddess is believed to work in close conjunction with the spirits of ancestors to produce the moral code by which the community lives and regulates its affairs. The moral code as sanctioned by Ala and the ancestral spirits as given in prohibitions and customary taboos is spoken of in Igbo as nso-ala (abominations against the earth goddess).

Among the moral prohibitions regarded as nso-ala are homicide, incest, stealing of yams (the staple food of the Igbo), etc. Any person known to have committed any of these abominations is severely punished. Hence the moral lapse of an individual constitutes an offence against the earth goddess and the ancestral spirit. This results to punishments for all the members of the community unless the proper propitiation and restitution, where necessary, are carried out.

The ancestors are also believed to be offended by the moral lapses of their offspring. Unless proper propitiations are offered to them calamity would befall the community. Thus the function of upholding public and private morality in any given Igbo society is the concern of the community rather than the concern of the inner motive of the individual. It is believed that the spirits of departed members of the extended family are never far away, and that they are ready to take active part in all matters pertaining to the welfare 
of the 'family' or of the community. Parrinder cited in Ulogu (1985) is of the opinion that this strong belief in the continuity of the group with its past members found in most parts of West Africa is the basis of much ethical consideration of this people.

The cult of the ancestral spirits has another ethical dimension. Not all dead ancestors automatically become 'saints' to be revered. Those who lived bad life and died in uncommon circumstances never qualified for such place of honour. Therefore what one does in his life time helps to create what place his spirit would occupy among the dead ancestors. This helps in rooting moral life into the web of the people in a manner that discourages simple and individual self-seeking relativism in ethical considerations. As long as the ancestral spirits are pleased with proper sacrifices, propitiation and ceremonial attention, they are believed to guarantee life and amicable relationships in the community. They can even intervene with the gods of the spiritual world on behalf of the living and prevent the evil divinities from carrying out their diabolic designs against the living.

\section{Characteristics of Igbo Traditional Ethics}

Igbo traditional ethics is characterized by three main features: prohibitions, taboos and customs (Ulogu, 1985). Prohibitions include general prescriptions which we have mentioned earlier on such as (i) Do not take the life of a member of the community; (ii) Do not steal, especially yams, the staple food of the people; (iii) Do not commit incest; (iv) Do not defraud strangers. These prohibitions as we have already noted, although partially moral in content, are rooted in religious beliefs and observances connected with Ala, the earth divinity. 
Most taboos are means of social control and do not strictly come under ethics. But because contravention of any taboo results in disturbance of the equilibrium between the living and the dead, between the sacred and the profane, leading to disruption of the life of the community, taboos have acquired moral dimensions in Igboland and have therefore become one of the three features of Igbo morality. By their clear cut prescriptions, taboos build up a society, they do provide for such society structures of social expectations by which norms of social behaviour are generated.

Customs make up the third feature of Igbo morality. The word omenala (the traditions of the land) is used to describe the great mass of cultural and normal activities which are commonly referred to as customs. Customs lay down what is lawful or unlawful. These customs range from very serious subjects like the moral sanctions used in social control, to the more minute demands of etiquette and polite behaviour. Like prohibitions and taboos, customs are additional means of enforcing conformity. The values of society are said to be summed up in these customs which are also believed to have had their origin and sanction from the ancestral spirits and Ala (the earth divinity).

Apart from these three features of Igbo morality which we have been discussing as prohibitions, taboos and customs, there are the practical things which are definitely regarded as immoral such as poisoning others' food by the use of concocted potion or witchcraft, plotting to deprive a person of his rightful possession, duplicity, deep rooted anger that has the quality of poisoning relationship, inability to restore what has been given to some one for safe custody, the wagging tongue that indulges in speaking evil against others and by so doing the person becomes one in whom no 
confidence can be reposed or to whom no words of honour and counsel can be addressed.

\section{Essential Values of the Decalogue and Igbo Traditional Ethics}

One can deduce from the Decalogue and Igbo traditional ethics some essential values for community building. The possession of the values enables a person and a people to face the challenges of community development. Some of these values include sense of the sacred, unity and fidelity.

\section{i. Sense of the Sacred}

This concerns the effective understanding of the force of truth. It is founded on the virtue of humility by which one knows the other. The sense of the sacred manifests and gives meaning to the Ten Commandments and Igbo traditional morality respectively. It is the sense of the sacred that underlies a person's attitude towards God, God's name and reverence for God on the Sabbath. Sense of the sacred is, and is of, self-possession, self-realization and Godrealization. An incident in the Old Testament can throw light on the sense of the sacred. When King David was trying to transfer the Ark of God from the house of Abinadab to Jerusalem, it happened that Uzzah touched the Ark. God struck him and he died immediately (I Chr. 13:10). David became afraid. Instead of taking the Ark to Jerusalem, he left it in the house of Obed-Edom. Again, when Saul was pursuing David to kill him, suddenly David found him asleep and was tempted to kill him. David refused saying: God forbid that I should raise my hand against Yahweh's anointed (1 Sam. 26:11). The sin against the sacred is called sacrilege. Likewise, in Igbo society, the sacred permeates every aspect of life. 


\section{ii. Unity}

Unity is a cosmic value. It is universal value. The wise say that unity is strength. Hence the saying: United we stand, divided we fall. The Decalogue bears the mark of unity among the Jews. This unity is reflected in some lines of the Ten Commandments especially in $9^{\text {th }}$ and $10^{\text {th }}$ commandments. For Jesus, the unity of believers is an index of credibility. Jesus prayed in John 17:23, "May they be perfected in unity". It is one of the marks of the Church. The Igbo usually use the broom to demonstrate the power of unity. It is said that a single broom stick can easily be broken, but when united with others, it is very difficult. Unity is therefore fundamental in community building. Unity does not exist without love. Hence love is the basis of unity.

\section{iii. Fidelity}

Fidelity is the soul of life. It is keeping one's word. The Decalogue and Igbo traditional ethics encourage fidelity among the Jews and the Igbo respectively. Without fidelity, covenant (igba-ndu) has no meaning. Infidelity is the opposite of fidelity. Another name for infidelity is corruption. In fact infidelity or lack of personal commitment is the reason for the present economic recession in Nigeria. The Bible explains the death of Saul thus:

Thus died Saul in the infidelity of which he had been guilt towards Yahweh, in that he had no obeyed the word of Yahweh, and because he had consulted a necromancer for guidance. He had not consulted Yahweh, who therefore caused his death and transferred the monarchy to David, son of Jesse (1Chr. 10:13-14).

These three values work together for the good of the community. Without them community building is very difficult. 


\section{The Decalogue and the Challenges of Igbo Community Building}

Igbo community building is both a felt need and a gigantic task. There are a number of indicators to show that Igboland is passing through challenges of community development. The first index is the dying Igbo language. When a nation losses her language, she virtually dies. Language is a powerful instrument of community development. There is an organization in Igboland called 'Otu Subakwanu Igbo' which is eager to regenerate interest and pride in Igbo language. This organization, as crucial as it is, is yet to attract spontaneous Igbo encouragement in both cash and kind. If nothing is done drastically, then this generation of the Igbo no matter how educated is a lost Igbo age. Very little can be done without a people's language.

The second index is that Igbo people fought a devastating civil war which lasted from 1967 to 1970 . After the Nigeria-Biafran war a socio-cultural organization was formed by name Ohaneze NdiIgbo, to unite Igbo people from within so that Igbo people could gradually get over the wounds of the war while growing stronger within. It is common knowledge that this great initiative has been crippled from within by division.

The third index is that Igboland was infected by the "Divided Christianity". Thus Igbo land is populated by many churches and religious movements which have kept both the people and land divided. These Igbo Christians do not see themselves as one. This counts for unfriendly relationship that is often observed among the different Christian denominations in Igboland. It is necessary for the Igbo Christians to come together as a people and build their 
land. It is unfortunate and shameful that the Igbo have not embraced love for one another as basis for meaningful community building.

The fourth index is the persisting inferiority complex implanted by racism on Igbo culture and past. We seem to be afraid to celebrate our history and appreciate our heroes and ancestors. Ekwunife (1990) did an extensive research on the different traditional activities of the Igbo community which include the consecration of the day, the week, the season from January to December for various activities. One discovers that whatever an Igbo person is, has and does is connected with God. Most of these were discounted because of the different teachings of different missionaries. In this age of inter-faith dialogue, ecumenism, religious freedom, and inculturation, it is necessary to revisit these abandoned harmless practices.

The fifth index is the growing anxiety that Igbo people are loosing out on the political scene. It has been observed that every Igbo elite wants to be President of Nigeria. In the end none has enough support. Politics is a game of number. When there are many Igbo people contesting to be President of Nigeria, for instance, the aspirants will end up sharing the votes of their Igbo supporters thereby loosing the election. It is high time the Igbo community began to inculcate unity and solidarity as reflected in the Decalogue and Igbo traditional morality for meaningful community building.

The Ten Commandments can provide an insight to address these challenges of Igbo community building. This insight comes from $9^{\text {th }}$ and $10^{\text {th }}$ commandments: Thou shall not covert your 
neighbour's house and wife and whatever that is his. The Igbo word for this 'good of the other' is $o k u$. God orders that $o k u$ should be respected. $O k u$ can be described as the total legitimate possession or wealth of a person, family or community. It includes what is inherited, added by acquisition and passes from one generation to another. This oku unites and connects all the commandments. $O k u$ is life. The foundation of $o k u$ is God. Parents make oku possible. Other commandments show how one can preserve the other's oku for everything revolves around oku. Oku gives meaning and concreteness to the sense of the sacred - who is who, what is what, where, when, how and for what. Oku gives meaning to unity. Here is the convergence of meaning, work, worship and duty. Oku is belongingness. Oku gives meaning to fidelity. Being is action. $O k u$ is therefore at the heart of community building. Without oku there is no community. It is therefore important to appreciate that the Decalogue is at the center of Igbo community existence. $O k u$ is pure responsibility. It connotes security. Thus $o k u$ is fundamental to the covenant or Igba $n d u$.

There are seven levels of $o k u$ in the world. These levels are united and connected. They include: personal $o k u$, family $o k u$, town $o k u$, ethnic oku, country oku, oku Chukwu (ultimate foundational meaning), and Eternal oku (ultimate goal, oku kpom-kwem). These basic classes or levels of $o k u$ are linked to each other. The person is linked to the family, the family linked to the town, the town to ethnic group, the ethnic group to the country, and the country to the world, to God and eternity. Each entity must prepare to engage in the oku game. This game is measured by leadership and the diversity and unity of experts in strategic positions. Those who lack courage, confidence and competence are out mastered and put 
off the game. Everything is happening in the presence of God, the oku master.

Experience teaches that once your oku is penetrated, it is hard to recover. Thus the Bible encourages all to be awake, sober and vigilant. With this Igbo community can overcome the problems of ignorance, arrogance and forgetfulness that militate against personal and community building.

\section{Conclusion}

The study has discussed the Decalogue and Igbo traditional ethics and their essential values for Igbo community development. It has shown that the Ten Commandments can be used to understand the challenges of Igbo community building, and bring out the ways to tackle the challenges. Much can be achieved, if the people are exposed to the meaning and dimensions of $o k u$ in $9^{\text {th }}$ and $10^{\text {th }}$ commandments. $\mathrm{Oku}$ is largely God with us. It is our all inclusive wealth, our yesterday, today and tomorrow, visible and invisible. With it we are united and connected with each other and, all over the world in God. Oku is worth dying for, Jesus did, and many followed his example.

Ikenna L. Umeanolue

Nnamdi Azikiwe University, Awka

\& Emmanuel C. Anizoba

University of Nigeria, Nsukka 


\section{References}

Arazu, R. C. (1994). Covenant broken and reconciliation. Enugu: Liz.

Clifford, R. J. (2000). Exodus. In R.E. Brown, J.A. Fitzmyer and R.E. Murphy (Eds.). The new Jerome biblical commentary (pp. 44-79). London: St Pauls.

Ekwunife, A. N. O. (1990). Consecration in Igbo traditional religion. Enugu: Snaap.

McLaughlin, J.F. (1929). Exodus. In F.C. Eiselen, E. Lewis and D.G. Downey (Eds.). The Abingdon Bible commentary (pp. 249-277). New York: Abingdon.

Kizhakkeyil, S. (2009). The Pentateuch: An exegetical commentary. Bandra: St Paul.

Madu, J. E. (2004). Honest to African cultural heritage. Onitsha: Coskan Associates.

Nzomiwu J. P. C. (1999). The concept of justice among the traditional Igbo: An ethical inquiry. Enugu: Snaap.

Park, J.E. (1952). Exodus. In G.A. Buttrick (Ed.). The interpreter's Bible (pp. 833-1099). New York: Abingdon.

Ulogu, E. (1985). Igbo life and thought. Onitsha: University Publishing Company 